\title{
Stakeholder salience, positive CSR news and the market value of banks
}

\author{
Andrea Pérez , Carlos López-Gutiérrez , María Del Mar García-De Los \\ Salmones \& Paula San-Martín
}

To cite this article: Andrea Pérez, Carlos López-Gutiérrez, María Del Mar García-De Los Salmones \& Paula San-Martín (2020) Stakeholder salience, positive CSR news and the market value of banks, Spanish Journal of Finance and Accounting / Revista Española de Financiación y Contabilidad, 49:4, 483-502, DOI: 10.1080/02102412.2019.1681718

To link to this article: https://doi.org/10.1080/02102412.2019.1681718

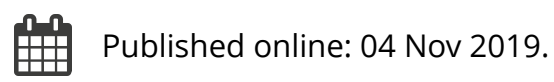

Submit your article to this journal $x$

\section{Џll Article views: 70}

Q View related articles $\sqsubset$

View Crossmark data $\asymp$

4 Citing articles: 1 View citing articles 


\title{
Stakeholder salience, positive CSR news and the market value of banks
}

\author{
Andrea Pérez (D), Carlos López-Gutiérrez (D), María Del Mar García-De Los Salmones \\ and Paula San-Martín (iD)
}

Business Administration Department, University of Cantabria, Santander (Cantabria), Spain

\begin{abstract}
This research explores the effects that media coverage of corporate social responsibility (CSR) news related to investor, customer, employee and community issues has on the market value of Spanish banks, measured as the impact generated in abnormal returns for these companies. We use an event study with a sample of 190 positive CSR articles published online between 2015 and 2018 in the most important Spanish business newspaper according to its diffusion rate. The findings demonstrate that positive CSR news related to investor, customer, employee and community issues generates positive abnormal returns for listed banks. In the $[-1,+1]$ window, positive investor news has notably larger effects on the abnormal returns for these companies than positive news related to customer, employee and community issues, which have similar effects.
\end{abstract}

\section{La relevancia de las partes interesadas, las noticias positivas de RSC y el valor de mercado de los bancos}

\section{RESUMEN}

Esta investigación explora los efectos que la cobertura mediática de las noticias de responsabilidad social corporativa (RSC), relacionadas con temáticas de inversores, clientes, empleados y sociedad, tiene sobre el valor de mercado de los bancos españoles, medido este indicador como el impacto generado en los retornos anormales de estas empresas en el mercado de valores. Para cumplir con este objetivo, utilizamos un estudio de eventos con una muestra de 190 artículos de RSC publicados entre 2015 y 2018 en la versión online del periódico económico español más importante según su tasa de difusión. Los resultados demuestran que las noticias de RSC relacionadas con temáticas de inversores, clientes, empleados y sociedad generan retornos anormales positivos para los bancos que cotizan en bolsa. En la ventana $[-1,+1]$, las noticias positivas para los inversores tienen efectos notablemente mayores sobre los retornos anormales de estas empresas que las noticias positivas relacionadas con temáticas de clientes, empleados y sociedad, que tienen efectos similares.

\section{ARTICLE HISTORY}

Received 7 May 2018

Accepted 11 October 2019

\section{KEYWORDS}

Corporate social responsibility; market value; media; stakeholders; salience

PALABRAS CLAVES responsabilidad social corporativa; valor de mercado; medios de comunicación; grupos de interés; saliencia

CONTACT Andrea Pérez perezran@unican.es Business Administration Department, University of Cantabria, Avda. Los Castros s/n, Santander (Cantabria) 39005, Spain 


\section{Introduction}

The significant effect of media coverage of corporate social responsibility (CSR) news on the market value of listed companies has been well established in the literature (Flammer, 2013). Scholars argue that the media affects the stock market by functioning as an independent monitor of company practices that safeguards the interests of their stakeholders (Tang, 2012). More precisely, the media not only echo social concerns, but are also conceived as educating stakeholders, influencing their expectations and perceptions (Husillos, LarrinagaGonzález, \& Álvarez-Gil, 2011). When the media disseminate CSR information, they therefore affect the public agenda and help materialise the goals of companies by shaping their corporate reputations (Tang, 2012; Zhang \& Swanson, 2006). CSR information thus becomes a critical and necessary element with which to facilitate the identification of socially responsible companies on financial markets (López-Arceiz, Bellostas-Pérezgrueso, Moneva-Abadía, \& Rivera-Torres, 2018).

Along this line, previous studies have focused on exploring the effect of different types of CSR news on the abnormal returns for listed companies. Researchers have mostly explored the effects of environmental news (Connors, Johnston, \& Silva-Gao, 2013; Flammer, 2013; Gregory, Tharyan, \& Whittaker, 2014; Xu, Zeng, \& Tam, 2012), labour issues (Gregory et al., 2014) and philanthropy news (Gregory et al., 2014; Patten, 2008). For instance, information on environmental releases (e.g. chemicals and toxics emissions, polluting practices) is an important nonfinancial performance measure to include in estimation models in some economic sectors, such as the chemical or the electric utility industries (Connors et al., 2013). Similarly, employee strengths are significantly and positively correlated with market value, while labour concerns are significantly and negatively correlated with a company's abnormal returns (Gregory et al., 2014). Previous findings highlight that negative information about community and philanthropic issues is especially valued by shareholders, although the effect of positive information on market value is less conclusive (Gregory et al., 2014).

Nevertheless, a close look at the evidence provided by researchers in this line of study suggests gaps in literature that have still not been addressed. Although some relevant CSR news has been explored, previous researchers have neglected the study of market reactions to other important types of CSR news, such as news related to customer or investor issues. The managerial perspective of stakeholder theory (Freeman, 1984), however, suggests that customers and investors are some of the most salient stakeholders for companies because of their ability to threaten a company's existence in terms of cash flow and funding (Mitchell, Wood, \& Agle, 1997). It is therefore expected that CSR news concerning customers and investors will also have significant effects on market value (Pérez, García de Los Salmones, \& López-Gutiérrez, 2015), although this idea has not yet been explored in-depth. The lack of studies on these two CSR areas indicates that the current picture held by researchers and practitioners regarding the effect of CSR news on market value is incomplete and, further study is needed to explore all types of CSR news completely.

Additionally, there has been little comparison in previous studies of potential differences in significance and intensity in the effect of each type of CSR news on the market value of companies (Gregory et al., 2014). Although there is evidence that different types of positive CSR news have positive effects on the market value of companies, so far little is 
known about whether all types of positive CSR news provoke exactly the same reactions from shareholders or, conversely, whether there is positive CSR news that results in larger or stronger abnormal returns for companies (Halme \& Laurila, 2009; Verbeeten, Gamerschlag, \& Möller, 2016). Stakeholder theory suggests that salience is a key construct in understanding the role of stakeholders in company decision-making (Mitchell et al., 1997). More precisely, stakeholder groups may have different levels of power against companies and their claims may differ in urgency and legitimacy. This being so, according to the managerial perspective of stakeholder theory, it is expected that companies and their shareholders will give priority to more salient stakeholders (i.e. groups with more powerful, urgent and legitimated claims) because their business benefits depend on them to a larger extent (Clarkson, 1995). Thus, not all types of positive CSR news are expected to report the same financial benefits for listed companies. The lack of comparison of positive CSR news demonstrates that little specific is yet known about how the relationship between CSR news and market value is articulated.

The main goal of our paper is thus focused on providing an empirical analysis to clarify how media coverage of different CSR news, including investor, customer, employee and community news, affects the market value of listed banks in Spain. The main contributions of the paper are in identifying the salience of various types of CSR news for shareholders and providing useful guidance to help banks to better articulate their CSR and communication strategies. We selected the banking industry as the focus of our research for several reasons. First, banks usually attract most media attention on CSR issues due to the particular consequences, in terms of reputation and image, suffered from this industry after the 2007-2008 Great Recession (Pérez et al., 2015). Second, our principal aim in the paper is to study if there are any differences in the impact of CSR news on market value depending on the stakeholder that is most significantly affected by the news. For this purpose, it is necessary that each stakeholder has the same importance for all the companies included in the sample, which only happens when companies work in the same industry.

The remainder of the paper is structured as follows. We review the existing literature on the media coverage of CSR news and its impact on the abnormal returns for companies in the financial market. Based on stakeholder theory, the literature review leads to the proposal of our research hypotheses, which compares market reactions to a sample of four types of positive CSR news (investor, customer, employee and community) published between 2015 and 2018 and related to the banks listed in the Spanish Stock Exchange during the whole period. The method is described, paying especial attention to the research design and the sample of positive CSR news collected for the study. Third, the research findings are presented and discussed. Finally, we summarise the most relevant conclusions, managerial implications, limitations and future lines of research from the study.

\section{Literature review}

\section{CSR news and market value}

Corporate social responsibility (CSR), which refers to the activities of a company that demonstrate the inclusion of economic, social, and environmental concerns in its business actions and in interactions with stakeholders (Pérez \& López-Gutiérrez, 2017), has gained 
attention in the business world, especially since the beginning of the Great Recession in 2007. It is generally agreed that awareness of CSR actions is a fundamental precondition of benefits related to CSR for companies. Companies are facing increasing pressure from stakeholders to engage in CSR and are expected to communicate their CSR efforts accordingly (Verbeeten et al., 2016).

In responding to these pressures, companies communicate CSR information to stakeholders through a diverse range of channels, including annual reports, corporate websites, advertising or media releases (Nekhili, Nagati, Chtioui, \& Rebolledo, 2017). The media is presented as one of the most influential sources of public opinion in the context of CSR (von Sikorski \& Müller, 2018), due to its agenda-setting effect, which suggests that the media has a specific ability to influence the salience of CSR news and its impact on the public (Tang, 2012; Zhang \& Swanson, 2006). It is also important to note that, contrary to self-reported information, the media do not tend to avoid negative or potentially harmful information, and it does not suffer from the few incentives that exist for companies to disclose information in areas where they have a poor track record (Nekhili et al., 2017).

CSR news has a great effect on the market value of companies because it serves as a reliable source of corporate information for external stakeholders, especially shareholders. This stakeholder group is principally interested in assessing the risk and expected future profitability of companies (Ortas \& Moneva, 2011). Media coverage of CSR news provides shareholders with critical information that directly affects a company's future cash flows and earnings, in addition to financial information. More extensive CSR news therefore decreases information asymmetry between corporate managers and capital market participants (Feng, Chen, \& Tseng, 2018), and may reduce the overall information gathering costs and transaction costs of shareholders (Cormier, Ledoux, \& Magnan, 2011; Dhaliwal, Li, Tsang, \& Yang, 2011). Similarly, improving the amount and tone of CSR news concerning a company can generate competitive advantages that should be valued by shareholders, such as improvements in the company's goodwill, image in the community and socio-political legitimacy (Flammer, 2013; Kim \& Kim, 2014; Patten, 2008). Numerous empirical papers have demonstrated the significant impact of CSR news on the market value of listed companies (Byun \& Oh, 2018; Connors et al., 2013; Flammer, 2013; Kim \& Kim, 2014; Ortas \& Moneva, 2011; Patten, 2008; Zhang, Wang, \& Fung, 2014)

The relevance of CSR news for shareholders is especially significant during or after unexpected declines in the general level of trust in listed companies (Lins, Servaes, \& Tamayo, 2017), such as the current situation following the last international recession. Outside shareholders are likely to be more concerned that the financial information they previously relied upon to guide investment decisions may not be credible, and as such, they will seek metrics such as CSR information that speak to a company's values and integrity more often, placing a valuation premium on companies that are deemed to be more trustworthy (Lins et al., 2017).

\section{Stakeholder theory and the salience of CSR news}

Companies may embark on CSR actions for numerous reasons, including institutional ones (Godos-Díez, Fernández-Gago, Cabeza-García, \& Martínez-Campillo, 2014). At the institutional level, there may be pressure from stakeholders based on their expectations 
regarding CSR (Godos-Díez et al., 2014), or companies may engage in CSR due to the influence of events that question company legitimacy (Husillos et al., 2011).

From the institutional perspective, stakeholder management is thus regarded as the practical means by which companies fulfil their social responsibilities (Varenova, Samy, \& Combs, 2013). Stakeholder theory (Freeman, 1984) can provide a solid framework for understanding the effect of CSR news on market value (El Ghoul, Guedhami, \& Kim, 2017; Nekhili et al., 2017). This theory asserts that a company can be viewed as a set of interdependent relationships between stakeholders, which comprise not only shareholders but also all groups who can affect or be affected by the company's activities (Clarkson, 1995). Stakeholder theory states that a company's success, including financial performance, depends largely on its ability to comply with stakeholder expectations and to meet their diverse information-related needs (Nekhili et al., 2017). This is because the way that the company deals with stakeholder claims helps it to obtain necessary resources, enhance its wealth-generation capacity and improve stakeholder support (El Ghoul et al., 2017; Ortas \& Moneva, 2011). From this perspective, CSR information is a major element that companies can employ to manage or respond to their various stakeholders (investors, customers, employees, community, etc.) to gain their support and approval (Gray, Kouhy, \& Lavers, 1995).

The managerial (Freeman, 1984) or instrumental (El Ghoul et al., 2017) perspective of stakeholder theory nonetheless recognises that companies interact differently with stakeholders based on their salience (i.e. importance) so that they can comply with their expectations and achieve legitimacy to operate more easily (Pérez, López-Gutiérrez, \& García de Los Salmones, 2017). Stakeholder salience refers to a combination of stakeholder power, legitimacy and urgency (Ullmann, 1985). Power means that a stakeholder can make a company do something that it would not otherwise have done; that is, the stakeholder can certainly exert their influence on the company. Legitimacy exists when the stakeholder's demands conform to the norms, values and beliefs of the wider community (Mitchell et al., 1997). That is, legitimacy is closely linked to the general belief that stakeholders' claims are proper, desirable or appropriate (Thorne, Ferrell, \& Ferrell, 2003). There is urgency in the manager-stakeholder relationship when stakeholders want their wishes to be fulfilled quickly because their demands are time-sensitive and important (Thorne et al., 2003).

Stakeholders can be classified into three different groups based on their salience (Mitchell et al., 1997). Managers perceive 'definitive stakeholders' as those that embody all three of the stakeholder attributes (i.e. power, legitimacy and urgency). 'Expectant stakeholders' possess only two of the attributes described by Mitchell et al. (1997), and they are perceived as only moderately salient for companies (Pérez et al., 2017) because either they lack power to enforce change or lack urgency or legitimacy to demand it (Dong, Burritt, \& Qian, 2014). Third, 'latent stakeholders' are a low-salience class of stakeholder possessing only one attribute and having the least power to seek change in company activities (Dong et al., 2014). This classification suggested by Mitchell et al. (1997) is also in accordance with the definition of audiences as primary or secondary stakeholders (Pérez et al., 2017). Primary stakeholders are highly salient groups without whose continuing participation the company cannot survive as a going concern. Conversely, secondary stakeholders are those who are not engaged in transactions with the company and are not essential for its survival (Clarkson, 1995). 
Stakeholders exhibiting both power and legitimacy, and with an urgent claim, mean managers have a clear and immediate mandate to give priority and attend to that stakeholder's claim (Dong et al., 2014). The more salient the stakeholder to the company, the more effort will be exerted in managing the relationship (Mitchell et al., 1997). The more salient the stakeholder, the more CSR actions the company will thus implement and, accordingly, the more CSR news will be expected to appear in media. It can also be anticipated, based on the relationship between CSR news and market value previously drafted in this paper, that the more salient the stakeholder, the stronger the relationship between CSR news related to that specific stakeholder and the market value of the company will appear. This is because, as shareholders are primarily worried about future cash flow and corporate profitability (Ortas \& Moneva, 2011), it is expected that they will particularly appreciate CSR news concerning stakeholders that are more powerful in determining those future cash-flows (Halme \& Laurila, 2009; Hillman \& Keim, 2001; van der Laan, van Ees, \& van Witteloostuijn, 2008). These stakeholders will garner the greatest power, legitimacy and urgency in their claims on the company.

It is still not clear which specific stakeholders should be included in corporate decision-making, however, and what their salience status is (Hine \& Preuss, 2009). There is still a dichotomy of narrow and wide stakeholder approaches, and the most salient stakeholders for companies in diverse industries still needs further definition (Pérez et al., 2017). As previous studies have demonstrated, the attention that companies pay each stakeholder group has changed throughout history (Morf, Flesher, Hayek, Pane, \& Hayek, 2013) and it is also significantly dependant on the type of industry in which the companies operate (Pérez et al., 2015; von Sikorski \& Müller, 2018).

\section{The salience of CSR news in the banking industry}

The reputation and image of the banking industry has particularly suffered the consequences of the Great Recession (Pérez et al., 2015). The subprime debacle, the bankruptcies and the buyouts and bailouts of hundreds of financial institutions in numerous countries, have stressed the moral crisis that lay at the root of the recession and for which the banking industry is seen as one of the immediate causes (de Bondt, 2013). There is therefore a lack of confidence in banks nowadays and there is a growing impression that virtually all those in positions of leadership are less concerned with truth and the public good than they used to be (Lins et al., 2017). In this situation, scholars and practitioners agree that no economic or reputation recovery can be achieved without restoring an ethos of social responsibility in the sector (de Bondt, 2013), which justifies the relevance of CSR for companies in this particular industry.

Furthermore, and because of the financial and reputational consequences of the recession for companies, bank stakeholders are expected to fall into different groups according to the managerial perspective of the stakeholder theory previously described in this paper. The classification of bank stakeholders as definitive, expectant or latent stakeholders (Mitchell et al., 1997) may have a significant impact on the effect of each type of CSR news on the market value of listed banks, which is the main hypothesis of this study. 
For instance, nowadays investors are expected to meet the requirements for power, legitimacy and urgency better than other bank stakeholders, which positions them as 'definitive stakeholders' in this industry (Pérez et al., 2015). Investors have always been considered one of the most powerful stakeholder groups of a company (Mitchell et al., 1997). Even though the power of other stakeholders may change over time (Morf et al., 2013), the power of investors is much more stable because they control money, which is the most critical resource for the continued viability of a bank. Additionally, in periods of low profitability and in situations of high debt, the economic demands of investors will take priority over the social demands of other stakeholder groups (Ullmann, 1985). This idea supports the legitimacy and urgency of investor demands in periods that follow severe economic recessions. It is also important to note that outside investors who finance companies face a great risk, because the returns on their investments cannot materialise if the controlling shareholders or managers expropriate them (Cruz-Suárez, Díez-Martín, Blanco-González, \& Prado-Román, 2014). Investor protection turns out to be crucial for banks in the context of CSR.

Banks strongly depend on customers because of their ability to threaten a company's existence in terms of lost business and future cash flows (Elijido-Ten, Kloot, \& Clarkson, 2010). Customers also have the power and legitimacy needed to be considered salient stakeholders. Nevertheless, the protection that commercial laws offer to customers in most countries after the recession explains why there have not been significant problems in this area since their promotion and implementation, especially in Spain (Gómez \& Lyczkowska, 2014; Represa, 2009). The demands of customers are not currently a priority in the public agenda and their urgency seems to be subordinated to other priority issues such as financial issues or corporate and political corruption (Palau \& Davesa, 2013). Customers are expected to be classified as 'expectant stakeholders' in the current Spanish banking industry (Pérez et al., 2015).

Another 'expectant stakeholder' group is bank employees. Employees fall under what Elijido-Ten et al. (2010) define as the 'company power relationship', that is, they are stakeholders who depend on the company for their economic survival and stability. This idea was especially true in the Spanish context after the economic recession. The Spanish unemployment rate, which fell from $22 \%$ in 1994 to $8 \%$ in 2007, had reached $19 \%$ by the end of 2009 (Bentolila, Cahuc, Dolado, \& Barbanchon, 2010) and was $21 \%$ when the data for this study was first collected in 2015. The Great Recession meant that millions of Spanish employees were laid off, and the contracts for those who kept their jobs have become more precarious, and many have experienced cuts in hours worked, wages and other benefits as companies seek to reduce labour costs in order to remain afloat (Verick, 2009). Additionally, the national government has implemented several measures to achieve labour market flexibility and companies have used these measures to continue offering temporary and precarious positions (Bentolila et al., 2010). Employee claims are thus very legitimate and urgent in Spain, however, this stakeholder group somehow lacks power and, as so, its salience is now only moderate (Pérez et al., 2017).

Finally, philanthropic and environmental issues involving the social community are also expected to have an impact on the market value of listed banks, according to all the previous empirical support in this line of research (Connors et al., 2013; Flammer, 2013; Gregory et al., 2014; Patten, 2008; Xu et al., 2012). The effect of this news on the abnormal returns for listed banks is expected to be lower than that of other stakeholder, however, because they refer to 
'latent stakeholders' (van der Laan et al., 2008). Although citizens and special groups within this category have some influence over companies due to their capacity to mobilise public opinion in favour of (or in opposition to) a company's activities, the community is classified as a stakeholder group that is not essential for a company's survival. The community does not maintain frequent nor direct exchanges with companies. On the contrary, it involves implicit relationships and the company's dependence on them is weak (van der Laan et al., 2008). A company's relationship with the community is more likely to produce moral capital (versus the exchange capital of 'definitive stakeholders' and 'expectant stakeholders') and to be viewed as voluntary, related on some occasions to social beneficence based on normative or pragmatic appeals (Godfrey, Merrill, \& Hansen, 2009). Furthermore, many CSR actions focused on the community (e.g. environmental issues) do not always have an effect on profit in the short term (Verbeeten et al., 2016), especially in the banking industry, which is not a highly-polluting sector (Connors et al., 2013). A community's CSR claims are therefore expected to be legitimate, but this stakeholder group is not expected to be perceived as powerful nor urgent for banks, so that CSR news which focuses on it may report the lowest positive returns to listed companies. Actually, previous research has shown that companies still do not widely participate in broader societal issues such as human rights issues, fighting poverty and hunger or Third World development, which means that further work should be done on proving to companies that the community should be considered in the wide sense (Varenova et al., 2013).

We therefore propose that CSR news related to 'definitive stakeholders' (i.e. investors) will generate larger abnormal returns for listed banks, followed by CSR news related to 'expectant stakeholders' (i.e. customers and employees) and 'latent stakeholders' (i.e. community). The main hypotheses of the paper are thus presented as follows:

H1: CSR news related to investor issues will have a larger and stronger effect on the abnormal returns for listed banks than CSR news related to (a) customer, (b) employee and (c) community issues.

H2: CSR news related to (a) customer and (b) employee issues will have a larger and stronger effect on the abnormal returns for listed banks than CSR news related to community issues.

\section{Empirical study}

\section{Data collection and processing}

In order to identify CSR news we examined the content of 'Expansión', the leading business newspaper in Spain according to its audience and diffusion volumes (OJD, 2019), from 1 January 2015 to 31 December 2018. Although there are other general and business newspapers in Spain that also publish CSR news, most of this information comes from communication agencies (e.g. Agencia EFE, Europa Press) that disseminate the pieces of news to all these newspapers equally. As such, most of the national newspapers publish very similar CSR content, and it is common to find the same CSR headlines published in different sources at the same time. We therefore believe that exploring the content of the leading business newspaper in the country would result in a sufficiently representative sample of CSR news to implement a robust analysis in this paper. 
Using the list of keywords suggested by Pérez et al. (2015), we identified CSR news related to the banks listed in the Spanish Stock Exchange during the four year period analysed in the study (i.e. Bankia, Bankinter, BBVA, CaixaBank, Liberbank, Sabadell and Santander) by searching the online database of the newspaper. All the keywords referred to CSR issues that related to the economic, social and environmental responsibilities of banks to each of the groups that have a stake in them.

The initial screening of the newspaper's library allowed us to identify 480 pieces of CSR news. Some news referred to stakeholders who were not included in the four main stakeholder groups explored in this paper and the number of articles related to each was also too small to guarantee robustness. Some pieces of CSR news were also identified as relating to more than one stakeholder group at once. For instance, some pieces of news covered the closing of banking offices due to the restructuring of banks, which affects both job creation and stability among employees, and also customer services, relationships, communication and dialogue mechanisms. Because it was usually difficult to discern which stakeholder group was more significantly affected by the content of each specific piece of news, we only retained the pieces of CSR news that were clearly related to only one stakeholder.

We therefore only included pieces of CSR news that were clearly and uniquely related to the four key stakeholders previously discussed in this paper (Fombrun, Gardberg, \& Sever, 2000): (1) investors, (2) customers, (3) employees and (4) the community. Investor issues referred to complaint procedures, investor relations, communication and dialogue mechanisms, and the provision of all required information to credit rating agencies and shareholder rights. Customer issues referred to competitive prices and payment conditions, customer service, relationships, communication and dialogue mechanisms, the development of products to meet the special needs of the disadvantaged customers, high innovation and accessibility, high product quality, health and safety and standards, voluntary codes and transparency for advertising and marketing practices. Employee issues included topics related to equal opportunities, freedom of association, collective bargaining and complaint procedures, job creation and stability, social benefits and training and development. Finally, community issues included topics related to economic development programs, educational and cultural contributions, environmental policies, systems and performance and social and charitable contributions.

At this point in the filtering procedure, we noted that there were few pieces of CSR news that were expected to have a negative impact on the market value of listed banks, especially in the community and investor domains. For the purpose of this study we therefore decided to focus exclusively on positive pieces of CSR news.

It was also observed that some of the pieces of positive CSR news identified for the analysis referred to the same CSR story, although at different times. This is because newspapers usually continue to publish information about the same event while it is still important for their readers. In these cases, we decided to retain only the first article that referred to each specific CSR story because it was expected to have the largest impact on the market value of listed banks.

We also checked that no other news about each bank had been published during the largest period that was explored in this study to avoid bias in the results due to the presence of contaminating events in the same period. Applying this filter meant that several pieces of positive CSR news were deleted from our database. 
After all these filters were applied, the final database was comprised of 190 pieces of positive CSR news. For each piece of CSR news that we explored, the following items were identified: (1) date; (2) name of the company, (3) newspaper headline, (4) stakeholder group and (5) CSR issue.

\section{Characterisation of CSR news}

The 190 positive CSR articles identified for the study related to the seven banks listed in the Spanish Stock Exchange (BME) as follows: Bankia ( $\mathrm{n}=33,17.37 \%)$, Bankinter $(\mathrm{n}=28$, 14.74\%), BBVA ( $\mathrm{n}=32,16.84 \%)$, CaixaBank $(\mathrm{n}=34,17.89 \%)$, Liberbank $(\mathrm{n}=18,9.47 \%)$, Sabadell $(\mathrm{n}=16,8.42 \%)$ and Santander $(\mathrm{n}=29,15.27 \%)$. They were also distributed among the four stakeholder groups as follows: investors $(n=16,8.42 \%)$, customers $(n=91,47.89 \%)$, employees $(n=20,10.53 \%)$ and community $(n=63,33.16 \%)$. A detailed description of the sample of articles used in the study is presented in Table 1.

\section{Event study methodology}

We employed an event study with daily returns to analyse the market reaction to positive CSR news (McWilliams \& Siegel, 1997). Although event studies have made an enormous contribution to capital markets research in recent decades, their contribution continues to expand, not only in accounting and finance but in many other disciplines (Corrado, 2011). Specifically, event studies have been extensively applied to analyse market reactions to CSR announcements and news in different research contexts, aiming to determine whether a single event (i.e. CSR announcement or piece of news) affects shareholder decisions or results in abnormal share price volatility (Clacher \& Hagendorff, 2012; Feng et al., 2018; Wang \& Chen, 2017). The proposal of these studies is that changes in the market value of companies around an event date can be interpreted as the net present value of future costs and benefits associated with CSR disclosures (Johannesen \& Larsen, 2016).

Event studies analyse stock price changes around the date of a CSR announcement by estimating abnormal returns, defined as the difference between the return actually obtained on a given date and the expected return according to a market model previously defined by the researchers (McWilliams \& Siegel, 1997). The market model originally proposed by Fama, Fisher, Jensen, and Roll (1969), which assumes that the residuals of the market model are independent and identically distributed, is frequently used to calculate abnormal returns. However, Binder (1985) identifies several problems in Fama et al.'s (1969) assumptions, mostly because abnormal returns, which are the residuals of their model, are likely to

Table 1. Characterisation of CSR news.

\begin{tabular}{lccccc}
\hline Banks & $\mathrm{N}$ & Investors & Customers & Employees & Community \\
\hline Bankia & $33(17.37 \%)$ & $4(2.11 \%)$ & $17(8.95 \%)$ & $3(1.58 \%)$ & $9(4.73 \%)$ \\
Bankinter & $28(14.74 \%)$ & $2(1.05 \%)$ & $20(10.53 \%)$ & $4(2.11 \%)$ & $2(1.05 \%)$ \\
BBVA & $32(16.84 \%)$ & $0(0.00 \%)$ & $12(6.32 \%)$ & $5(2.63 \%)$ & $15(7.90 \%)$ \\
CaixaBank & $34(17.89 \%)$ & $2(1.05 \%)$ & $10(5.26 \%)$ & $2(1.05 \%)$ & $20(10.53 \%)$ \\
Liberbank & $18(9.47 \%)$ & $1(0.53 \%)$ & $13(6.84 \%)$ & $1(0.53 \%)$ & $3(1.58 \%)$ \\
Sabadell & $16(8.42 \%)$ & $1(0.53 \%)$ & $9(4.73 \%)$ & $2(1.05 \%)$ & $4(2.11 \%)$ \\
Santander & $29(15.27 \%)$ & $6(3.15 \%)$ & $10(5.26 \%)$ & $3(1.58 \%)$ & $10(5.26 \%)$ \\
$\mathrm{N}$ & $190(100 \%)$ & $16(8.42 \%)$ & $91(47.89 \%)$ & $20(10.53 \%)$ & $63(33.16 \%)$ \\
\hline
\end{tabular}


differ across companies. The residuals are also not independent when different pieces of news are published on the same date and when companies in the same industry are analysed.

We applied a multivariate regression model (MVRM) to calculate the abnormal returns in our study (Binder, 1985), which alleviates the concerns of previous studies based on the methodology proposed by Fama et al. (1969). As Ortas and Moneva (2011) pointed out, when using the MVRM methodology the model incorporates heteroskedasticity and contemporaneous correlations between equations and that allows findings to be robust to the event clustering problems identified by Binder (1985). The MVRM methodology computes the abnormal returns for each company $\left(\gamma_{i a}\right)$ by estimating the following model:

$$
R_{i t}=\propto_{i}+\beta_{i} R_{m t}+\sum_{a=1}^{A} \gamma_{i a} D_{a t}+\mu_{i t}
$$

where $R_{i t}$ is the return obtained by company $i$ on day $t$ and $R_{m t}$ the return of the financial market (IBEX35 index in Spain) on day t. $\mathrm{D}_{\text {at }}$ are dummy variables that equal one in each day that is included in the event window, and zero otherwise. This approach allows the individual abnormal returns (gammas) to differ across companies. We calculated the average abnormal returns as the average of the abnormal returns obtained for each company. The model is estimated from 270 days before to 21 days after the event date.

The MVRM methodology also allows the significance of the average cumulated abnormal returns (ACAR) to be tested in order to analyse the market reaction for several days around the event date. In the present research, different event windows were chosen to include possible reactions in the share prices before and after the event date. This method allows us to control for possible leaks or rumours that can advance the reaction of the market at the date of the announcement, or publication on a date when the market is closed (McWilliams \& Siegel, 1997). In order to estimate when the market reaction occurred, we calculated daily abnormal returns around the event date (Menéndez \& Gómez-Ansón, 2003) in a window of 7 days $[-3,+3]$. Based on these abnormal returns, we defined the event windows to be considered for the study, only including those days where statistical significance appeared. Using windows of variable duration means that we can also homogenise the returns of all the companies considered for the study and avoid the bias that an inaccurate delimitation of the event window can produce.

\section{Findings}

Table 2 presents the daily abnormal returns observed for the global sample of positive CSR news and the average cumulated abnormal returns in the event windows considered. The evolution of the daily abnormal returns is shown in Figure 1, where daily and cumulative abnormal returns are presented. The event windows are formed considering those days where the abnormal returns are statistically significant. For each event window, Table 2 shows the average cumulated abnormal return (ACAR) and the test of statistical significance.

Table 2 and Figure 1 show that the highest daily abnormal returns amount to $0.46 \%$ on day 0 , which is a statistically significant result at the 0.01 level. Abnormal returns are 
Table 2. Event study results (global sample of news).

\begin{tabular}{lccc}
\hline \multicolumn{2}{l}{ Total number of CSR news $(\mathrm{N}=190)$} & & \\
\hline Days & Daily abnormal returns & sig. & Cumulative abnormal returns \\
\hline$[-3]$ & $0.00 \%$ & & $0.00 \%$ \\
{$[-2]$} & $0.09 \%$ & $* * *$ & $0.09 \%$ \\
{$[-1]$} & $0.24 \%$ & $* * *$ & $0.33 \%$ \\
{$[0]$} & $0.46 \%$ & $* *$ & $0.79 \%$ \\
{$[1]$} & $0.25 \%$ & $* *$ & $0.84 \%$ \\
{$[2]$} & $-0.20 \%$ & & $0.84 \%$ \\
{$[3]$} & $0.00 \%$ & sig. & \\
Event windows & $\mathrm{ACAR}$ & $* * *$ & \\
{$[-1,0]$} & $0.71 \%$ & $* * *$ & \\
{$[-1,+1]$} & $0.95 \%$ & $0.76 \%$ & \\
{$[-1,+2]$} & &
\end{tabular}

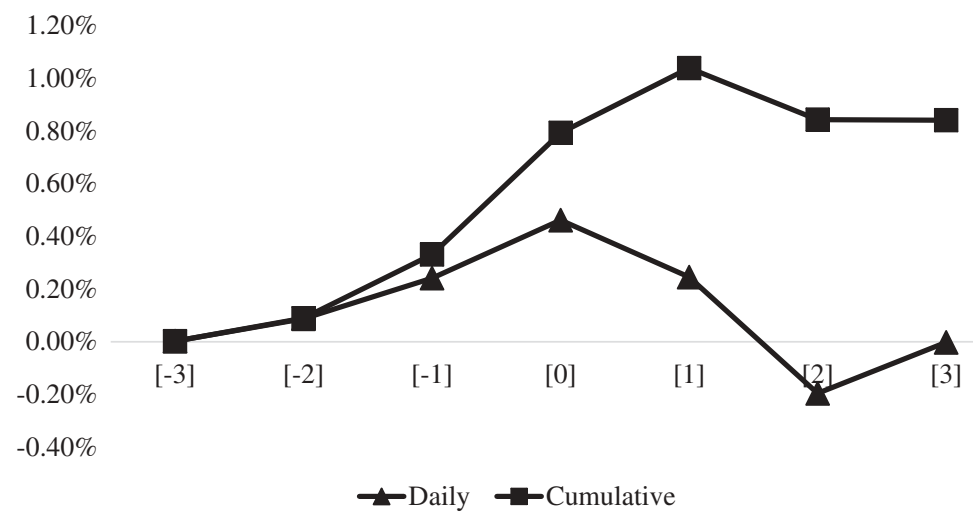

Figure 1. Daily and cumulative abnormal returns around the event day.

also statistically significant on days $-1,+1$ and +2 . Based on these results, we perform the subsequent analysis using three different event windows $([-1,0] ;[-1,+1] ;[-1,+2])$.

As shown in Table 2, there are statistically significant abnormal returns in the days around the event date for all the event windows considered in the study. Thus, media coverage of a bank's positive CSR news generates significant and positive abnormal returns for these companies in the three event windows considered for the study. The findings also show that the largest market reaction appears in the days immediately around the event date. Some of the reaction is distributed between the day before (i.e. $[-1,0]$ window) and the day after the event date (i.e. $[-1,+1]$ window). These findings explain why the greatest ACAR to positive CSR news $(0.95 \%)$ occurs in the $[-1,+1]$ window, which takes into account not only the event date but also the days immediately before and after it. Our results also show that the financial market reacts very quickly to the release of positive CSR news, and that the effect dilutes gradually over time (see Figure 1).

Table 3 presents the results of the event study implemented for each type of positive CSR news explored in this paper (i.e. investor, customer, employee and community news). Table 3 also compares dimensions in the $[-1,0],[-1,+1]$ and $[-1,+2]$ windows. 


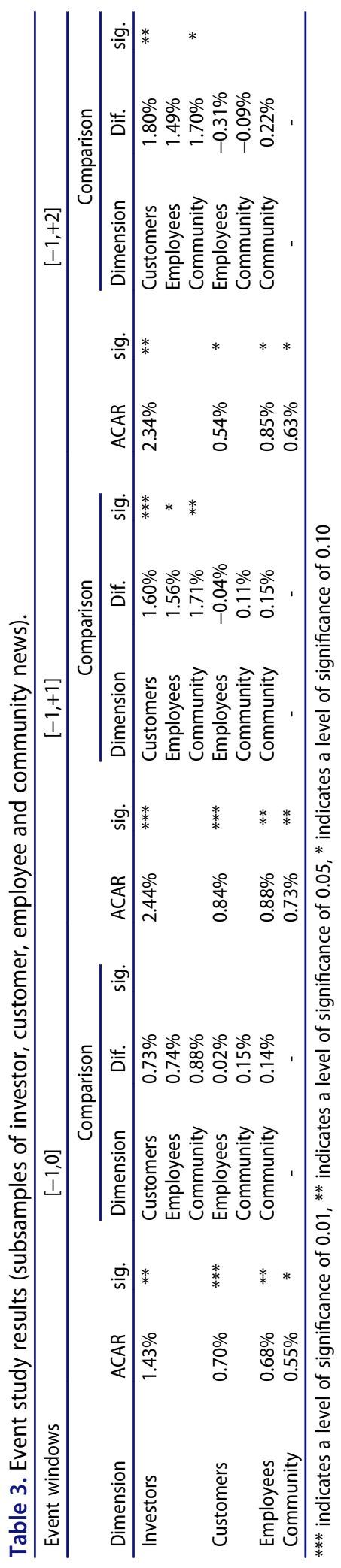


We used the Wilcoxon rank-sum test to test whether the differences in the magnitude of the reactions are statistically significant.

Similarly to the findings reported when CSR news is analysed globally, Table 3 shows that all types of positive CSR news generate positive abnormal returns for Spanish listed banks. The magnitude of the reaction presents different patterns among dimensions, however. For instance, pieces of positive CSR news that discuss investor issues generate the largest ACAR for companies, with the greater ACAR occurring in the $[-1,+1]$ window. The ACAR is $1.43 \%$ in the $[-1,0]$ window, then it increases to $2.44 \%$ in the $[-1,+1]$ window and, after that, the effect loses relevance in the wider $[-1,+2]$ window, although this ACAR is still significant. The same pattern is observed for positive CSR news that focuses on customer issues. In this case, there is a significant ACAR of $0.70 \%$ in the $[-1,0]$ window and $0.84 \%$ in the $[-1,+1]$ window. Nonetheless, its decrease over time is even stronger than for investor news, as the ACAR in the $[-1,+2]$ window is only $0.54 \%$. The same time pattern is observed for employee and community news. In both cases, abnormal returns are statistically significant in the $[-1,0]$ window, they increase in the $[-1,+1]$ window and finally decrease over time. For instance, positive employee news has an effect on the market value of banks of $0.68 \%$ in the $[-1,0]$ window, $0.88 \%$ in the $[-1,+1]$ window and a small decrease to $0.85 \%$ in the $[-1,+2]$ window. Similarly, positive community news has an effect on the market value of banks of $0.55 \%$ in the $[-1,0]$ window, $0.73 \%$ in the $[-1,+1]$ window and $0.63 \%$ in the $[-1,+2]$ window.

To compare the differences in the significance of market reactions among dimensions, Table 3 also contains the ACAR's difference with the other dimensions in all the windows considered. The findings of this last analysis show that the most significant differences between dimensions appear in the $[-1,+1]$ window. In this window, the highest abnormal returns are observed for news related to investor issues and their differences with customer, employee and community issues are statistically significant. Nonetheless, it is also observed that these differences do not exist in the shorter $[-1,0]$ window, and they also lose significance when a longer $[-1,+2]$ window is considered. More precisely, although the difference between investor news and customer and community issues is still significant in the $[-1,+2]$ window, the statistical significant difference with employee news disappears. The findings of the study therefore support hypotheses H1a, H1b and $\mathrm{H} 1 \mathrm{c}$, but only partially because the intensity of the reaction is only statistically different among dimensions in the $[-1,+1]$ and $[-1,+2]$ windows. It therefore seems that, although at a different pace, the impacts of all the dimensions tend to homogenise when wider event windows are considered. As for the differences in the impacts of the other three types of CSR news (i.e. customer, employee and community news) on the market value of banks in the Spanish Stock Market, Table 3 shows that no statistically significant difference exists in any of the event windows considered for the analysis. Hypotheses $\mathrm{H} 2 \mathrm{a}$ and $\mathrm{H} 2 \mathrm{~b}$ are therefore not supported by the findings of our paper.

\section{Discussion}

The findings of the study confirm the relevance of the media's coverage of positive CSR news in satisfying banks' financial goals because these types of news increase their market value and generate positive abnormal returns for them. Although the effect in market value is relatively small, which is in accordance with findings in previous studies (Curran 
\& Moran, 2007), it is still significant and positive. The reaction of the financial market to positive CSR news is immediate, since the most intense effect of CSR news on the abnormal returns for banks occurs in the three-day window around the event date [i.e. $[-1,+1]$ window $]$, and diminishes over time. This finding is consistent with the results reported by previous scholars, such as Shane and Spicer (1983), who show that the average abnormal returns aggregated for the dates around the release of the first environmental report of a company are much larger than for the following days and even reports.

The findings also confirm that the publication of any type of positive CSR news related to investor, customer, employee or community issues offers positive returns to Spanish listed banks (Connors et al., 2013; Flammer, 2013; Gregory et al., 2014; Xu et al., 2012). Nonetheless, there are relevant differences in the magnitude of the financial market reaction.

For instance, investor news presents the greatest impacts on the market value of banks in all the temporary windows studied, and the difference is statistically significant in the $[-1,+1]$ window and also partially in the $[-1,+2]$ window. Stakeholder theory argues that investors are among the most powerful, legitimate and urgent stakeholders for companies (Mitchell et al., 1997). They are especially considered 'definitive stakeholders' in the banking industry (Pérez et al., 2015). Our findings locate employee news as the second dimension with the largest impact on the market value of banks in the three event windows. Therefore, and despite being subordinate to investor concerns, shareholders appreciate positive employee news (Feng et al., 2018; Verbeeten et al., 2016) and employees can be considered as 'expectant stakeholders' in the banking industry (Pérez et al., 2015). The effect of customers on market value is the third largest in magnitude if the $[-1,0]$ and $[-1,+1]$ windows are considered, thus corroborating the idea that customers are another 'expectant stakeholder' that reports positive results for companies once investor interests are covered. Nonetheless, the findings concerning this dimension differ to some extent from our expectations, because it is observed that its effect on market value dilutes significantly over time, much more than how the effect of other types of CSR news dilutes in the end. Finally, positive CSR news focused on community issues has a smaller impact on abnormal returns for banks in the Spanish Stock Exchange, at least in the $[-1,0]$ and the $[-1,+1]$ windows. This finding also aligns with the principles of stakeholder theory, in the sense that a community is expected to be a 'latent stakeholder' (van der Laan et al., 2008). Nevertheless, the findings are contrary to our previous expectations in the sense that, from the day before the positive CSR news is released, community, customer and employee news are equally significant in terms of their impact on the cumulated abnormal returns of companies in the financial market.

\section{Conclusions, limitations and future lines of research}

In this paper, we explored the relationship that exists between the media coverage of diverse types of positive corporate social responsibility (CSR) news and the market value of Spanish banks. Most previous studies that have explored the relationship between CSR news and stock prices have focused on exploring only very specific CSR topics, mostly environmental, labour and philanthropic issues, and thus they have frequently ignored other relevant CSR news (e.g. investor and customer news), and also neglected to 
compare the differences in significance and intensity that may exist in the effect of each category on the abnormal returns for companies in the financial market. Stakeholder theory defends the multidimensional character of CSR and the large variety of stakeholder demands that companies should balance. Further research was needed to compare the effects of diverse types of CSR news on market value and reactions to media.

In summary, the findings reported in the paper suggest that media coverage of positive CSR news has a significant effect on the market value of Spanish banks. Roughly speaking, news that covers positive content related to a bank's CSR actions generates positive abnormal returns for these companies in the short term (i.e. at least up to a $[-1,+2]$ window). Investors are among the most salient stakeholders in the context of CSR and, consequently, the media's coverage of investor issues prompts the largest price reactions in the financial market. Abnormal returns to employee, customer and community news are also significant in all the event windows. However, reactions to customer news specially lose impact over time. The findings also show that there are significant differences in the effects of investor news on corporate market value when compared to customer, employee and community news, although the significant difference only occurs consistently in the $[-1,+1]$ window (and partially in the $[-1,+2]$ window).

These findings have significant implications for the management of CSR and media relations in companies, especially banks. First, companies should realise the importance that CSR has acquired in recent years, and it is recommended that they do not assume it as a cost but as an asset that provides notable competitive advantages. Companies should apply long-term strategic approaches to CSR because these types of news are important for shareholders and, consequently, they have significant and positive effects on market value. We would also like to highlight the importance that public relations acquires within companies in managing relationships with the media and improving the positive returns of CSR actions. A strongly designed public relations strategy would surely improve the publicity of positive news, which translates into increased market value, and can minimise the negative impact of CSR crises. Thirdly, our findings suggest that diverse CSR news is not equally salient for shareholders, in the sense that market reactions are different for news related to investor, customer, employee or community issues. Even though the differences in significance are not notably high, they are relevant for the temporary trend that each type of CSR news follows; that is, when they affect corporate market value. This suggests that it is important for companies to analyse the power, legitimacy and urgency of each stakeholder regularly to focus on those groups that have the greatest impact on the success of the corporate strategy in each specific period. Along these lines, one last important issue that CSR managers should take into account relates to the correct selection of the specific timing of CSR announcements. We know that the effect of this type of news is immediate, and news provokes a strong reaction in the shareholder's mind in the short term. Companies should thus select the announcement date carefully to maximise its positive impact on their market value.

Finally, this study is not without limitations and future research should consider them to improve knowledge about media, CSR news and market value. First, the study was only concerned with Spanish news, which limits the generalisability of the results to other research contexts. Previous scholars have demonstrated that country usually moderates the relationship between CSR and corporate financial performance, in such a way that the intensity of the relationship might not be the same across different economies (Miras- 
Rodríguez, Escobar-Pérez, \& Carrasco-Gallego, 2014). The findings reported in this paper for the banks listed in the Spanish Stock Exchange might differ from the findings that could be found in other national contexts. Similarly, the present paper was exclusively focused on the banking industry, whereas the effect of positive CSR news on the market value of companies might be different if other industry contexts were explored (Pérez et al., 2015). Future studies could also benefit from exploring the effect of CSR news on the market value of companies listed in socially responsible stock exchange indexes (e.g. Dow Jones Sustainability Indexes, FTSE4GOOD Indexes, Domini 400, etc.). From a business perspective, a company listed on any socially responsible equity index can obtain alternative funds from non-conventional investors who are more concerned about sustainable development and social well-being (Ortas \& Moneva, 2011). Because it is expected that CSR news resonates more in the minds of socially concerned investors, it would be interesting to explore whether the empirical results reported in this paper are corroborated in the context of the socially responsible stock exchange. The strict filtering procedure applied in our research also led to deleting pieces of CSR news from our database when they were expected to have a negative impact on the market value of listed banks. Future studies should expand the spectrum of CSR news in their databases to allow researchers to compare the effects of positive and negative news. Doing so would enrich the depth of the analysis and further relevant managerial implications for researchers and practitioners could be identified. Finally, the study only included articles published in a period of four years. This is a limitation because it means that the findings are likely to be affected by the specific economic, social or political situation of the country during that period. Future researchers should propose analyses that include a broader spectrum of media, countries, industries and periods in order to reduce the biases that may have been present in this paper.

\section{Disclosure statement}

No potential conflict of interest was reported by the authors.

\section{Funding}

Third-party funding was not received for this research.

\section{ORCID}

Andrea Pérez (D) http://orcid.org/0000-0003-3521-1783

Carlos López-Gutiérrez (D) http://orcid.org/0000-0003-1703-6440

María Del Mar García-De Los Salmones (D) http://orcid.org/0000-0001-5217-4553

Paula San-Martín (D) http://orcid.org/0000-0003-1699-4540

\section{References}

Bentolila, S., Cahuc, P., Dolado, J. J., \& Barbanchon, T. L. (2010). Unemployment and temporary jobs in the crisis: Comparing France and Spain (No. 2010-07). 
Binder, J. J. (1985). On the use of the multivariate regression model in event studies. Journal of Accounting Research, 23(1), 370-383.

Byun, S. K., \& Oh, J. M. (2018). Local corporate social responsibility, media coverage, and shareholder value. Journal of Banking and Finance, 87, 68-86.

Clacher, I., \& Hagendorff, J. (2012). Do announcements about corporate social responsibility create or destroy shareholder wealth? Evidence from the UK. Journal of Business Ethics, 106(3), 253-266.

Clarkson, M. B. E. (1995). A stakeholder framework for analyzing and evaluating corporate social performance. Academy of Management Review, 20(1), 92-117.

Connors, E., Johnston, H. H., \& Silva-Gao, L. (2013). The informational value of toxics release inventory performance. Sustainability Accounting, Management and Policy Journal, 4(1), $32-55$.

Cormier, D., Ledoux, M., \& Magnan, M. (2011). The informational contribution of social and environmental disclosures for investors. Management Decision, 49(8), 1276-1304.

Corrado, C. J. (2011). Event studies: A methodology review. Accounting and Finance, 51(1), 207-234.

Cruz-Suárez, A., Díez-Martín, F., Blanco-González, A., \& Prado-Román, C. (2014). Análisis de las relaciones entre la legitimidad organizativa, sus fuentes y dimensiones. Revista Venezolana de Gerencia, 19(65), 9-22.

Curran, M. M., \& Moran, D. (2007). Impact of the FTSE4Good index on firm price: An event study. Journal of Environmental Management, 82(4), 529-537.

de Bondt, W. (2013). After the crisis: How to restore trust in business and finance. Spanish Journal of Finance and Accounting, 42(157), 13-37.

Dhaliwal, D. S., Li, O. Z., Tsang, A., \& Yang, Y. G. (2011). Voluntary nonfinancial disclosure and the cost of equity capital: The initiation of corporate social responsibility reporting. Accounting Review, 86(1), 59-100.

Dong, S., Burritt, R., \& Qian, W. (2014). Salient stakeholders in corporate social responsibility reporting by Chinese mining and minerals companies. Journal of Cleaner Production, 84(1), $59-69$.

El Ghoul, S., Guedhami, O., \& Kim, Y. (2017). Country-level institutions, firm value, and the role of corporate social responsibility initiatives. Journal of International Business Studies, 48(3), 360-385.

Elijido-Ten, E., Kloot, L., \& Clarkson, P. (2010). Extending the application of stakeholder influence strategies to environmental disclosures: An exploratory study from a developing country. Accounting, Auditing \& Accountability Journal, 23(8), 1032-1059.

Fama, E. F., Fisher, L., Jensen, M. C., \& Roll, R. (1969). The adjustment of stock prices to new information. International Economic Review, 10(1), 1-21.

Feng, Z.-Y., Chen, C. R., \& Tseng, Y. J. (2018). Do capital markets value corporate social responsibility? Evidence from seasoned equity offerings. Journal of Banking and Finance, 94, 54-74.

Flammer, C. (2013). Corporate social responsibility and shareholder reaction: The environmental awareness of investors. Academy of Management Journal, 56(3), 758-781.

Fombrun, C. J., Gardberg, N. A., \& Sever, J. M. (2000). The reputation quotientSM: A multi-stakeholder measure of corporate reputation. Journal of Brand Management, 7(4), 241-255.

Freeman, R. E. (1984). Strategic management: A stakeholder approach. Boston, MA: Pittman.

Godfrey, P. C., Merrill, C. B., \& Hansen, J. M. (2009). The relationship between corporate social responsibility and shareholder value: An empirical test of the risk management hypothesis. Strategic Management Journal, 30(4), 425-445.

Godos-Díez, J. L., Fernández-Gago, R., Cabeza-García, L., \& Martínez-Campillo, A. (2014). Determinants of CSR practices: Analysis of the influence of ownership and the management profile mediating effect. Spanish Journal of Finance and Accounting, 43(1), 47-68.

Gómez, F., \& Lyczkowska, K. (2014). Spanish courts, the court of justice of the European Union, and consumer law. InDret: Revista Para El Análisis Del Derecho, 4(October), 1-34. 
Gray, R., Kouhy, R., \& Lavers, S. (1995). Corporate social and environmental reporting. A review of the literature and a longitudinal study of UK disclosure. Accounting, Auditing \& Accountability Journal, 8(2), 47-77.

Gregory, A., Tharyan, R., \& Whittaker, J. (2014). Corporate social responsibility and firm value: Disaggregating the effects on cash flow, risk and growth. Journal of Business Ethics, 124(4), 633-657.

Halme, M., \& Laurila, J. (2009). Philanthropy, integration or innovation? Exploring the financial and societal outcomes of different types of corporate responsibility. Journal of Business Ethics, 84(3), 325-339.

Hillman, A. J., \& Keim, G. D. (2001). Shareholder value, stakeholder management, and social issues: What's the bottom line? Strategic Management Journal, 22(2), 125-139.

Hine, J. A. H. S., \& Preuss, L. (2009). "Society is out there, organisation is in here": On the perceptions of corporate social responsibility held by different managerial groups. Journal of Business Ethics, 88(2), 381-393.

Husillos, J., Larrinaga-González, C., \& Álvarez-Gil, M. J. (2011). The edmergence of triple bottom line reporting in Spain. Spanish Journal of Finance and Accounting, 40(150), 195-219.

Johannesen, N., \& Larsen, D. T. (2016). The power of financial transparency: An event study of country-by-country reporting standards. Economics Letters, 145, 120-122.

Kim, M., \& Kim, Y. (2014). Corporate social responsibility and shareholder value of restaurant firms. International Journal of Hospitality Management, 40, 120-129.

Lins, K. V., Servaes, H., \& Tamayo, A. (2017). Social capital, trust, and firm performance: The value of corporate social responsibility during the financial crisis. Journal of Finance, 72(4), 1785-1824.

López-Arceiz, F. J., Bellostas-Pérezgrueso, A. J., Moneva-Abadía, J. M., \& Rivera-Torres, M. P. (2018). The role of corporate governance and transparency in the generation of financial performance in socially responsible companies. Spanish Journal of Finance and Accounting, 47(1), 44-80.

McWilliams, A., \& Siegel, D. (1997). Event studies in management research: Theoretical and empirical issues. Academy of Management Journal, 40(3), 626-657.

Menéndez, S., \& Gómez-Ansón, S. (2003). Stock splits: Motivations and valuation effects in the Spanish market. Investigaciones Económicas, 27(3), 459-490.

Miras-Rodríguez, M. D. M., Escobar-Pérez, B., \& Carrasco-Gallego, A. (2014). Responsabilidad Social Corporativa y rendimiento financiero: Un meta-análisis. Spanish Journal of Finance and Accounting, 43(2), 193-215.

Mitchell, R. K., Wood, D. J., \& Agle, B. (1997). Toward a theory of stakeholder identification and salience: Defining the principle of who and what really counts. Academy of Management Review, 22(4), 853-886.

Morf, D., Flesher, D. L., Hayek, M., Pane, S., \& Hayek, C. (2013). Shifts in corporate accountability reflected in socially responsible reporting: A historical review. Journal of Management History, 19(1), 87-113.

Nekhili, M., Nagati, H., Chtioui, T., \& Rebolledo, C. (2017). Corporate social responsibility disclosure and market value: Family versus nonfamily firms. Journal of Business Research, 77, 41-52.

OJD. (2019). Información y Control de Publicaciones (OJD) website. Retrieved from http://www. introl.es

Ortas, E., \& Moneva, J. M. (2011). Sustainability stock exchange indexes and investor expectations: Multivariate evidence from DJSI-Stoxx. Spanish Journal of Finance and Accounting, 40(151), 395-416.

Palau, A. M., \& Davesa, F. (2013). The impact of media coverage of corruption on Spanish public opinion. Revista Española de Investigaciones Sociológicas, 144(1), 97-124.

Patten, D. M. (2008). Does the market value corporate philanthropy? Evidence from the response to the 2004 tsunami relief effort. Journal of Business Ethics, 81(3), 599-607. 
Pérez, A., García de Los Salmones, M. D. M., \& López-Gutiérrez, C. (2015). Corporate reputation in the Spanish context: An interaction between reporting to stakeholders and industry. Journal of Business Ethics, 129(3), 733-746.

Pérez, A., \& López-Gutiérrez, C. (2017). An empirical analysis of the relationship between the information quality of CSR reporting and reputation among publicly traded companies in Spain. Academia Revista Latinoamericana de Administracion, 30(1), 87-107.

Pérez, A., López-Gutiérrez, C., \& García de Los Salmones, M. D. M. (2017). An empirical exploration of the link between reporting to stakeholders and corporate social responsibility reputation in the Spanish context. Accounting, Auditing \& Accountability Journal, 30(3), 668-698.

Represa, M. S. (2009). Adaptation and reform of consumer law - Recent evolution of this sector in the Spanish legal system. Acta Universitatis Lucian Blaga, 23, 23.

Shane, P. B., \& Spicer, B. H. (1983). Market response to environmental information produced outside the firm. The Accounting Review, 58(3), 521-538.

Tang, L. (2012). Media discourse of corporate social responsibility in China: A content analysis of newspapers. Asian Journal of Communication, 22(3), 270-288.

Thorne, D., Ferrell, O., \& Ferrell, C. (2003). Business and society: A strategic approach to corporate citizenship. Boston, MA: Houghton Mifflin Company.

Ullmann, A. A. (1985). Data in search of a theory: A critical examnation of the relationships among social performance, social disclosure, and economic performance of U.S. firms. Academy of Management Review, 10(3), 540-557.

van der Laan, G., van Ees, H., \& van Witteloostuijn, A. (2008). Corporate social and financial performance: An extended stakeholder theory, and empirical test with accounting measures. Journal of Business Ethics, 79(3), 299-310.

Varenova, D., Samy, M., \& Combs, A. (2013). Corporate social responsibiltiy and profitability: Trade-off or synergy. Sustainability Accounting, Management and Policy Journal, 4(2), 190-215.

Verbeeten, F. H. M., Gamerschlag, R., \& Möller, K. (2016). Are CSR disclosures relevant for investors? Empirical evidence from Germany. Management Decision, 54(6), 1359-1382.

Verick, S. (2009). Who is hit hardest during a financial crisis? The vulnerability of young men and women to unemployment in an economic downturn (No. 4359). Bonn.

von Sikorski, C., \& Müller, L. (2018). When corporate social responsibility messages enter the news: Examining the effects of CSR-framed news on product purchasing intentions and the mediating role of company and product attitudes. Communication Research Reports, 35(4), 335-345.

Wang, Y.-S., \& Chen, Y.-J. (2017). Corporate social responsibility and financial performance: Event study cases. Journal of Economic Interaction and Coordination, 12(2), 193-219.

Xu, X. D., Zeng, S. X., \& Tam, C. M. (2012). Stock market's reaction to disclosure of environmental violations: Evidence from China. Journal of Business Ethics, 107(2), 227-237.

Zhang, J., \& Swanson, D. (2006). Analysis of news media's representation of corporate social responsibility (CSR). Public Relations Quarterly, 51(2), 13-17.

Zhang, L., Wang, T., \& Fung, H. (2014). Market reaction to corporate social responsibility announcements: Evidence from China. China \& World Economy, 22(2), 81-101. 